\title{
Development Theories and Development Experience:
}

Half a Century Journey

\author{
Vladimir Popov
}

New Economic School, Moscow

vpopov@nes.ru

\begin{abstract}
Resumo
Este trabalho examina o impacto que as teorias de desenvolvimento tiveram nas políticas de desenvolvimento e o impacto inverso dos atuais sucessos e insucessos no pensamento sobre desenvolvimento. Argumenta-se que o pensamento sobre desenvolvimento se encontra em uma "encruzilhada". Teorias desenvolvimentistas no período pós-guerra passaram por um ciclo completo. Desde o "big push" e ISI, passando pelo pensamento consensualmente neoliberal de Washington, chegando no entendimento que nem os trabalhos mais antigos, tampouco os novos trabalhos de engenharia abordam com sucesso a questão do desenvolvimento. Nesse meio tempo, "milagres econômicos" no leste da Ásia foram realizados sem muita confiança no histórico do pensamento desenvolvimentista. Ocorrendo simplesmente como experimentações de políticos com "mãos de ferro".
\end{abstract}

Palavras-chaves: Crescimento, Teorias, Experiência

\begin{abstract}
This paper examines the impact that development theories have had on development policies, and the inverse impact of actual successes and failures in the global South on development thinking. It is argued that development thinking is at the cross-roads. Development theories in the postwar period went through a full circle-from Big Push and ISI to neo-liberal Washington consensus to the understanding that neither the former, nor the later really works in engineering successful catch-up development. Meanwhile, economic miracles were manufactured in East Asia without much reliance on development thinking and theoretical background - just by experimentation of the strong hand politicians.
\end{abstract}

Key words: Growth, Theories, Experience. 
$\underline{A}$ s Leo Tolstoy claimed in "Anna Karenina”, "happy families are all alike; every unhappy family is unhappy in its own way". This wisdom, however, can be hardly applied to the development success of countries: it appears that success stories in the development and transition world are as different as they can be. It is not uncommon to come across contradictory statements about the reasons of economic success: economic liberalization and free trade are said to be the foundations of rapid growth in some countries, whereas successes of other countries are credited to industrial policy and protectionism; foreign direct investment that are normally considered as a factor contributing to growth, did not play any significant role in the developmental success of Japan, South Korea and pre-1990s China. Privatization of state enterprises, foreign aid, free trade, liberalization of the financial system, democratic political institutions - all these factors, just to name a few, are usually believed to be pre-requisites of successful development, but it is easy to point out to success stories, not associated with these factors.

In the 1970s the breathtaking economic success of Japan that transformed itself into a developed country just in two postwar decades was explained by "Japan incorporated" structure of the economy - special relations between (a) the government and companies (MITI), (b) between banks and non-financial companies (bank-based financial system), (c) between companies and workers (life time employment). After the stagnation of the 1990s, and especially after 1997 Asian financial crisis that affected Japan as well, these same factors were largely labeled as clear manifestations of "crony capitalism" that should be held responsible for the stagnation (POPOV, 2008).

In 1960 Rosentein-Rodan, widely regarded as the author of the Big Push theory, favo- red India, Burma, Argentina and Hong Kong as nations expected to achieve 3\% annual growth per capita for a 5 year period. India, Burma and Argentina all achieved about $1.5 \%$ growth, whereas Hong Kong did much better. Chile, Egypt, Ghana and Jordan were also named for their unusually good growth prospects. But no one seems to have selected South Korea or Taiwan (TOYE, 1989).

Today, the conventional wisdom seems to point out to democratic countries encouraging individual freedoms and entrepreneurship, like Mexico and Brazil, Turkey and India, as future growth miracles, whereas rapidly growing currently authoritarian regimes, like China and Vietnam or Iran and Egypt, are thought to be doomed to experience a growth slowdown, if not a recession, in the future. According to Goldstone (2009),

a country encouraging science and entrepreneurship will thrive regardless of inequality: hence India and Brazil, and perhaps Mexico, should become world leaders. But I say countries that retain hierarchical patronage systems and hostility to individualism and science-based entrepreneurship, will fall behind, such as Egypt and Iran.

According to another variety of this popular view, rapid growth could be achieved under authoritarian regime only at the catch up stage, not at the innovative stage: once a country approaches the technological frontier and it becomes impossible to grow just by copying innovations of the others, it can continue to advance only with free entrepreneurship, guaranteed individual freedoms and democratic political regime.

This may be true and may be not, we still do not have enough evidence for the innovationbased growth. For one thing, on all measures of patent activity, Japan, South Korea and China 
are already ahead or rapidly catching up with the US. The patent office of the United States of America, which consistently issued the highest number of patents since 1998, was overtaken in 2007 by the patent office of Japan. The patent office of China replaced the European Patent Office as the fourth largest office in terms of issuing grants (after Japan, the US and Korea). The number of resident patent filings per $\$ 1$ of GDP and \$1 of R\&D spending is already higher, sometimes considerably higher, in Japan, Korea and China than in the US (WIPO, 2009).

And the evidence for the catch up growth is controversial to say the least. Imagine, for instance, that the debate about future economic miracles is happening in 1960: some were betting on more free, democratic and entrepreneurial India and Latin America, whereas the other predicted the success of authoritarian (even sometimes communist), centralized and heavy handed government interventionist East Asia...

Ideas matter a great deal. As Karl Marx put it, "material force can only be overthrown by material force, but theory itself becomes a material force when it has seized the masses" (MARX-ENGELS READER, 1972, 60). However, development thinking of the second half of the XX century can hardly be credited for " $m a$ nufacturing" development success stories. It is difficult, if not impossible, to claim that either the early structuralist models of the Big Push, financing gap and basic needs, or the later neoliberal ideas of Washington consensus that dominated the field since the 1980s has provided crucial inputs to economic miracles in East Asia, for instance. On the contrary, it appears that development ideas, either misinterpreted or not, contributed to a number of development failures - USSR and Latin America of the 1960s-80s demonstrated the inadequacy of import-substitutions model (debt crisis of the 1980s in Latin
America and dead end of the Soviet type economic model in the 1970s-80s), whereas every region of developing world that became the experimental ground for Washington consensus type theories, from Latin America to Sub-Sahara Africa to former Soviet Union and Eastern Europe, revealed the flaws of neo-liberal doctrine by experiencing a slowdown or even a recession in the 1980s-90s.

To reiterate, neither structuralists, nor neo-classical developmental theoreticians can claim credit for at least one case of economic miracle. Big Push and import substitution models, as well as economic liberalization theories that inspired economic policies in different countries and different periods, never and nowhere led to outcomes that today could be characterized as economic, much less social, success.

The policy of multilateral institutions GATT/WTO, IMF, WB - could have been coherent in its own way: in different periods it was based on relatively coherent, even though not necessarily the same, set of economic theories. But this policy, as well as development theories, cannot be held responsible for engineering development successes, let alone economic miracles. Japan, Hong Kong and Taiwan, Singapore and South Korea, South East Asia and China achieved high growth rates without much advise and credits from IMF and the WB (and in case of Hong Kong, Taiwan and China - without being members of GATT/WTO for a long time).

Economic miracles were manufactured in East Asia without much reliance on development thinking and theoretical background just by experimentation of the strong hand politicians. The 1993 World Development Report "East Asian Miracle" admitted that non-selective industrial policy aimed at providing better business environment (education, infrastructure, 
coordination, etc.) can promote growth, but the issue is still controversial. Structuralists claim that industrial policy in East Asia was much more than creating better business environment (that it was actually picking up the winners), whereas neo-liberals believe that liberalization and deregulation should be largely credited for the success.

It is said that failure is always an orphan, where as success has many parents. No wonder, both neo-classical and structuralist economists claimed that East Asian success stories prove that they were saying all along, but it is obvious that both schools of thought cannot be right at the same time.

Why there emerged a gap between development thinking and development practice? Why development successes were engineered without development theories, whereas development theoreticians failed to learn from real successes and failures in the global South? It appears that development thinking in the postwar period went through a full evolutionary cycle from dirigiste theories of Big Push, financing gap and import substitution industrialization (ISI 1950-70s) to neo-liberal deregulation wisdom of "Washington consensus" (1980-90s), to the understanding that catch up development does not happen by itself in a free market environment, but with a lack of understanding what particular kind of government intervention is needed for manufacturing fast growth (2000 - onwards).

His paper examines the impact that development theories had on development policies, and the inverse impact of actual successes and failures in the global South on development thinking. It also seeks to examines the possibilities for the new development paradigm.

\section{The Big Push: Theories and Practice}

To what extent development thinking influenced actual policies in developing countries? Development efforts of the 1950s and 1960s were dominated by ideas of "Big Push," "Take off," "Incremental Capital-Output Ratio," "Two-Gaps," etc., all of which focused on aggregate growth rate to be achieved through large doses of physical capital investment. The logic was seemingly flawless: savings rate is low in developing countries, so they may stay in a bad equilibrium forever (development trap - just enough investment to create jobs for the new entrants into the labor force, but not enough to increase capital/labor ratio), unless there is a Big Push - mobilization of domestic savings or import of savings from abroad. The Big Push can ensure a transition to a good equilibrium, where it would be possible to stay on a growth trajectory. Savings gap is another side of the foreign exchange gap: not enough domestic savings to finance investment, not enough foreign exchange earned from export to finance imports of investment goods. What is the answer to the lack of savings to make investment needed to exit the poverty trap? Forced mobilization of domestic savings or foreign borrowings to finance import of machinery to carry out industrialization.

The Big Push ideas are usually attributed to Rosentein-Rodan (1943) and to Murphy, Shleifer, and Vishny (1989), but there were earlier predecessors in the 1920s - "the theory of primitive socialist accumulation" of Preobrazhensky (1926/1965) and the two sector Feldman-Mahalanobis model (FELDMAN, 1928/1964), which is now acknowledged by researchers ${ }^{1}$ and even

\footnotetext{
Bardhan (1993) writes about the emergence of development economics: "In the third decade of this century it briefly flourished in the Soviet Union, dwelling on the problems of capital accumulation in a dual economy and of surplus mobilization from agriculture, and on the characteristics of the equilibrium of the family farm: the best products of this period, the dual economy model of Preobrazhenski (1926 [1965]), the two-sector planning model of Feldman (1928 [1964]) and
} 
omniscient Wikipedia².

The Big Push in practice in the 1930s in the USSR was associated with enormous costs, but is exonerated by many even today as the only possible strategy to create heavy and defense industry in the agrarian country in the short period of time before the start of the Second World War (for a summary of debates see: SHMELEV, POPOV, 1989, Chapter 2). The share of investment in GDP increased from $13 \%$ in the late 1920 s to $26 \%$ in the 1930 s, annual grain procurements by the state doubled from $11 \mathrm{mln}$. tons to over $20 \mathrm{mln}$. tons over the same period, export of grain - the major source of hard currency needed to pay for the imported machinery - grew from virtually nothing in the 1920 s to $5 \mathrm{mln}$. tons in 1930-31 (fig. 7). Collective farms created in 1929-30 had to deliver grain to the state at symbolic prices (not even covering 10\% of the costs). The result was the reduction of peasants' consumption and the famine of 1932-33 that took 5 mln. lives.

Stalin (1976) claimed that this was the only possible strategy of rapid industrialization. " 'We are fifty to a hundred years behind the advanced countries. We have to make good this distance in ten years. Either we do this or they crush us...", - he said in 1931, exactly 10 years before the Nazi Germany invaded the USSR. He even claimed that the elimination of prohibition in 1926 (allowing the government to receive excise taxes from sales of alcohol) was a price to pay for the reluctance of Western countries to provide the USSR with credits for industrialization (see Box).

the peasant economy model of Chayanov (1925 [1966]) came to be regarded as landmarks in the post-World War II literature, after these works were translated into English".

2 Http://en.wikipedia.org/wiki/Mahalanobis_model
Figure 7. Grain production, procurement, and export in the USSR in the 1920s30s, million tons 


\section{BOX. Big Push Soviet style}

"When we introduced the vodka monopoly we were confronted with the alternatives:

either to go into bondage to the capitalists by ceding to them a number of our most important mills and factories

and receiving in return the funds necessary to enable us to carry on,

or to introduce the vodka monopoly in order to obtain the necessary working capital for developing our industry

with our own resources and thus avoid going into foreign bondage.

Members of the Central Committee, including myself, had a talk with Lenin at the time, and he admitted that if we failed to obtain the necessary loans from abroad we should have to agree openly and straightforwardly to adopt the vodka monopoly as an extraordinary temporary measure.

That is how matters stood when we introduced the vodka monopoly.

Of course, generally speaking, it would be better to do without vodka, for vodka is an evil. But that would mean going into temporary bondage to the capitalists, which is a still greater evil. We, therefore, preferred the lesser evil. At present the revenue from vodka is over 500 million rubles. To give up vodka now would mean giving up that revenue; moreover there are no grounds for asserting that this would reduce drunkenness, for the peasants would begin to distil their own vodka and to poison themselves with illicit spirits....

I think that we should, perhaps, not have to deal with vodka, or with many other unpleasant things, if the WestEuropean proletarians took power into their hands and gave us the necessary assistance. But what is to be done? Our West-European brothers do not want to take power yet, and we are compelled to do the best we can with our own resources. But that is not our fault, it is-fate.

As you see, our West-European friends also bear a share of the responsibility for the vodka monopoly.

Source: STALIN, J. (1927). Interview with Foreign Workers' Delegations. November 5, 1927. Works, Vol. 10, August - December, 1927. Foreign Languages Publishing House, Moscow, 1954 (Original source: Сталин И.В. Беседа с иностранными рабочими делегациями 5 ноября 1927 г. Сочинения. - Т. 10. - М.: ОГИЗ; Государственное издательство политической литературы, 1949. С. 206-238).

Soviet catch-up development, however, looked impressive until the 1970s. In fact, in the 1930s to 1960s, the USSR and Japan were the only two major developing countries that successfully bridged the gap with the West (figs.1, 2, 9). But high Soviet economic growth lasted only for less than two decades, whereas in East Asia, it continued for three to four decades, propelling Japan, South Korea, and Taiwan to the rank of developed countries.
Figure 8. Annual average labor productivity growth rates in Soviet economy, \%

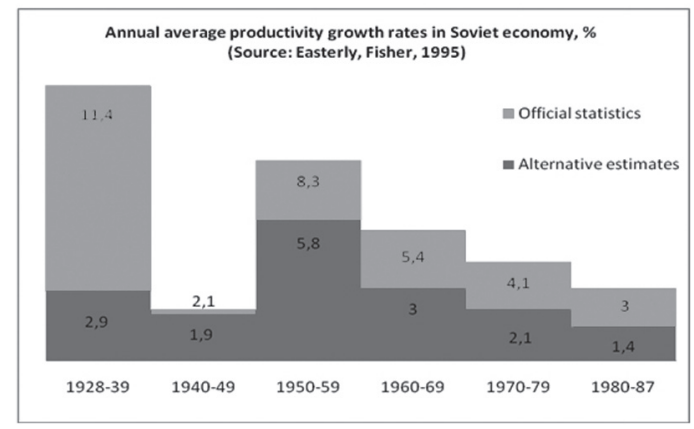

Source: EASTERLYT; FISHER, 1995.

Among many reasons for the decline in growth rate in the USSR in the 1960s-1980s, the inability of a centrally planned economy to ensure adequate flow of investment into replacement of retired fixed capital stock appears to be most 
crucial (Popov, 2007c). The task of renovating physical capital contradicted the short-term goal of fulfilling planned targets, and Soviet planners therefore preferred to invest in new capacities instead of upgrading old ones. Hence, after the massive investment of the 1930s in the USSR (the Big Push), the highest productivity was achieved after the period equal to the service life of capital stock (about twenty years) before there emerged a need for massive investment into replacing retired stock. Afterwards, capital stock started to age rapidly, sharply reducing capital productivity and lowering labor productivity and the TFP growth rate.

Figure 9. PPP GDP per capita in the USSR and Russia, \% of the US level

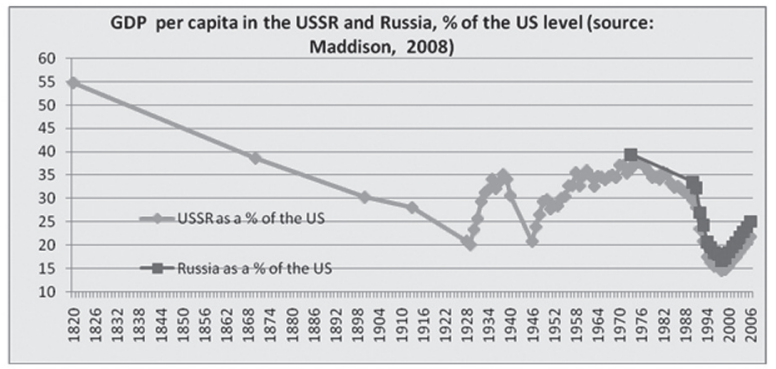

Source: MADDISON, 2008.

Table 1. Growth accounting for the USSR and Asian economies, Western data, 1928-87 (annual averages, \%)
If this explanation is correct, a centrally planned economy is doomed to experience a growth slowdown after three decades of high growth following a Big Push. In this respect, the relatively short Chinese experience with the CPE (1949/59-79) looks superior to the Soviet excessively long experience (1929-91). This is one of the reasons to believe that transition to the market economy in the Soviet Union would have been more successful if it had started in the 1960s.

The second major shortcoming of the Big Push strategy in the USSR was the excessive reliance on import substitution. Even in market economies that did not have the problem of replacing capital stock like the centrally planned economies, but that tried to carry out import substitution policies for too long the results were disappointing. In the 1950s-70s in Latin America, India, and Africa this strategy more often than not led to the creation of non-viable "white elephants" and "industrial dinosaurs" that could operate behind the wall of protection with implicit and explicit subsidies, but that failed to pass the efficiency test once they were exposed to the winds of international competition.

\section{Washington Consensus versus the Big Push}

After the debt crisis of the early 1980s and especially after the Soviet collapse in 1991,

\begin{tabular}{|l|c|c|c|c|c|}
\hline Period/ country & $\begin{array}{c}\text { Output } \\
\text { per } \\
\text { worker }\end{array}$ & $\begin{array}{c}\text { Capital } \\
\text { per } \\
\text { worker }\end{array}$ & $\begin{array}{c}\text { Capital/ } \\
\text { output } \\
\text { ratio }\end{array}$ & $\begin{array}{c}\text { TPF growth } \\
\text { (unit elasticity } \\
\text { of substitution) }\end{array}$ & $\begin{array}{c}\text { TPF growth assum- } \\
\text { ing 0.4 elasticity of } \\
\text { substitution }\end{array}$ \\
\hline USSR (1928-39) & 2.9 & 5.7 & 2.8 & 0.6 & \\
\hline USSR (1940-49) & 1.9 & 1.5 & -0.4 & 1.3 & \\
\hline USSR (1950-59) & 5.8 & 7.4 & 1.6 & 2.8 & 1.1 \\
\hline USSR (1960-69) & 3.0 & 5.4 & 2.4 & 0.8 & 1.1 \\
\hline USSR (1970-79) & 2.1 & 5.0 & 2.9 & 0.1 & 1.2 \\
\hline USSR (1980-87) & 1.4 & 4.0 & 2.6 & -0.2 & 1.1 \\
\hline & & & & & \\
\hline Japan(1950/57/65/-85/88/90) & & & $2.3-3.2$ & $1.7-2.5$ & \\
\hline Korea (1950/60/65-85/88/90) & & & $2.8-3.7$ & $1.7-2.8$ & \\
\hline Taiwan (1950/53/65-85/88/90) & & & $2.6-3.1$ & $1.9-2.4$ & \\
\hline
\end{tabular}

Big Push and ISI ideas were totally compromised and the pendulum of development thinking swung to the right excessive government intervention was proclaimed to be the major reason for development failures. The slogans of the day formulated in the Washington consensus were libe- 
ralization, deregulation, macro-stabilization, downsizing of the government, privatization, and opening up of closed economies - elimination of barriers in trade and capital flows (although not in international migration). Even East Asian success was explained mostly by deregulation and smaller size of the Asian governments.

The Structural Adjustment Programs (SAP) implemented in 1980s and 1990s focused on reduction of budget deficit, liberalization of prices, privatization of assets, liberalization of trade and investment, etc. They urged the debtdistressed countries to adopt "sensible economic policies", a term that encompassed not just macroeconomic stabilization on a grand scale but also microeconomic measures of thorough market liberalization. In 1988 this position was formalized; in a concordat aimed at improving policy coherence, the IMF and the World Bank agreed that adjustment lending would be available only to countries undergoing an IMF stabilization program (TOYE, 2009).

A further concordat was provoked in 1997-8 by wrangles over who had the right to do what during the Asian crisis. The establishment of the WTO introduced a third dimension to policy coherence. A three-way "Joint Declaration of Coherence", issued at the ill-fated Seattle Ministerial Meeting of the WTO (1999), emphasized their shared belief that trade liberalization was essential to the promotion of global growth and stability. It supported the use of informal cross-conditionality in lending to ensure that borrowing governments liberalized their trade regimes. In the last twenty years, IMF-BankWTO policy coherence has markedly increased, but it has been policy coherence in the service of the neo-liberal policy agenda (TOYE, 2009).

The results of the Washington consensus policies were even more frustrating than the results of the Big Push and ISI experiments. In 1980-2000 the gap between developed and developing countries actually increased for all regions of the South except for East Asia (O'CAMPO; JOMO; VOS, 2007). Over the 1980s, the economies of the middle income developing countries and of sub-Saharan Africa actually contracted. Transition economies in the 1990s experienced transformational recession that was either comparable (Eastern Europe) or greater in magnitude (former Soviet Union) than the Great Depression of the 1930s.

Meanwhile, East Asia, was growing several times faster than others (fig. 5).It was growing faster than other regions even in the 1950s70s, but this growth accelerated dramatically after the Deng's reforms in China 1979. From the 1980s India and South Asia became the second fastest growing region - their per capita GDP growth increased to 3\% a year in the 1980 s, $4 \%$ in the 1990s and 6-7\% in 2000-08. Fast Indian growth is sometimes attributed to the deregulation reforms of the 1990s, but it was shown that it actually started in the early 1980s, well before deregulation reforms were launched (GHOSH, $2007^{3}$ ). Like the Chinese, Indian growth was based on the achievements of the 1950s-70s period of ISI and mobilization of domestic savings: the savings rate (as a \% of GDP) doubled in recent 50 years, going up from $12-15 \%$ in the 1960 s, to $16-20 \%$ in the $1970 \mathrm{~s}, 15-23 \%$ in the $1980 \mathrm{~s}$, $23-25 \%$ in the 1990 s, and to $24-35 \%$ in $2000-08$ (WDI database).

With fast growth of East and South Asia the understanding that mobilization of domestic savings is crucial may be coming back. The Big Push ideas may be gradually returning now, albeit in a renewed form. "The UN Mil-

3 "It is now accepted that the shift to a higher economic growth trajectory in India came about not in the 1990s, after neo-liberal economic reforms, but a decade earlier, from the early 1980s" (GHOSH, 2007). 
lennium Project recommended in January 2005 "a big push of basic investments between now and 2015" while its Director suggests that " $[\mathrm{A}]$ combination of investments ... can enable African economies to break out of the poverty trap. These interventions need to be applied ... jointly since they strongly reinforce one another" (Sachs, 2005:208). British PM Blair's Commission for Africa launched a report that claims that "Africa requires a comprehensive 'big push' on many fronts at once.” In July 2005 the G-8 Summit similarly considered an increase in aid to Africa to finance such a 'Big Push”' (BEZEMER; DIRK \& DEREK HEADEY, 2006).

In fact, countries that managed to achieve high growth rates were mostly net creditors, not net borrowers; their current accounts were positive, i.e. they were saving more than they were investing (fig. 10). Even controlling for the level of development, PPP GDP per capita in the middle of the period, 1975, the relationship between the current account surplus and growth rates is still positive and significant:

$$
y=0.68 * \text { Ycap }+0.12^{* * *} C A+0.05 \text {, }
$$

$\mathrm{N}=91, \quad \mathrm{R}^{2}=0.23$, robust standard errors, T-statistics in brackets below,

where

$y$-annual average growth rates of per capita GDP in 1960-99, \%,

\begin{tabular}{|c|c|c|}
\hline Ycap & - & logarithm \\
\hline capita & PPP & GDP in \\
\hline
\end{tabular}

Figure 10. Average annual growth rates of GDP per capita and average current account as a \% of GDP, 1970-2007

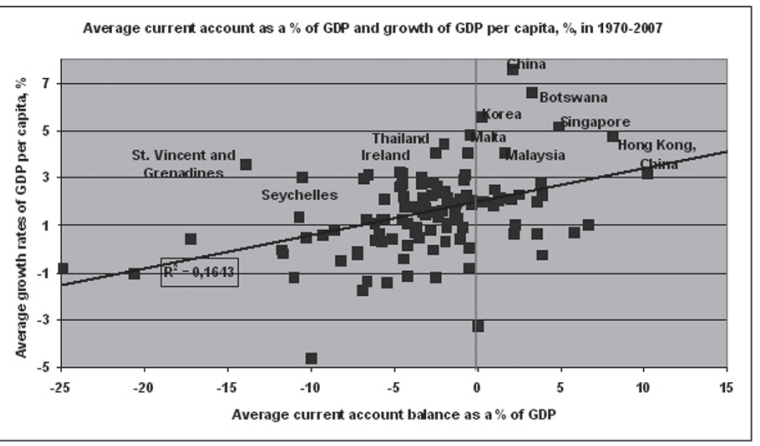

Source: WDI database.

This is known as the Feldstein-Horioka puzzle (FELDSTEIN; HORIOKA, 1980) - high correlation between domestic savings and investment even among countries with relatively open capital accounts, contrary to the prediction of the theory that capital should flow to countries with better investment climate and rates of return on investment. With high domestic savings rate comes high investment rate, which usually, although not always, leads to faster growth.

In the words of Paul Krugman (2009), since the early 1980s there have been three big waves of capital flows to developing countries, but none of them resulted in a growth miracle. "The first wave was to Latin American countries that liberalized trade and opened their markets in the wake of the 80s debt crisis. This wave ended in grief, with the Mexican crisis of 1995 and the delayed Argentine crisis of 2002.

The second wave was to Southeast Asian economies in the mid 90s, when the Asian economic miracle was all the rage. This wave ended in grief, with the crisis of 1997-8. 
The third wave was to eastern European economies in the middle years of this decade. This wave is ending in grief as we speak.

There have been some spectacular development success stories since 1980. But I'm not aware of any that were mainly driven by external finance. The point is not necessarily that international capital movement is a bad thing, which is a hotly debated topic. Instead, the point is that there's no striking evidence that capital flows have been a major source of economic success" (KRUGMAN, 2009).

In view of this evidence, the developing country policy choice of a determined attempt to rely on external financing is ironic. It is also ironic that while development economists are preoccupied by "capital flowing uphill” problem (from developing to developed countries), the best growth record is exhibited exactly by countries with positive current accounts and large reserve accumulation that are generating this uphill movement of capital.

Marshal plan for Western Europe right after the Second World War may have been the first and the last success story of foreign financing contributing substantially to economic revival. But even in this case it could be argued that without appropriate domestic (European) institutions and mobilization of domestic savings, the (relatively) rapid growth would not happen. Foreign financing of Japan after the Second World War was insignificant, whereas Japanese postwar growth was more impressive than European.

The same could be said about aid - official development assistance (ODA). Whereas from the point of view of a developing country, it is certainly better to have assistance from abroad than not to have it, aid alone cannot become a crucial factor promoting development. The sheer magnitude of aid (about $\$ 100$ billion annually) is too small to make a decisive difference $(0.3 \%$ of GDP of recipient countries, less than total net capital flows by the order of magnitude and several times smaller than just remittances from migrant labor). The irony also is that aid, emergency aid excluded, is usually used efficiently in countries that have relatively good institutional capacity and can mobilize domestic savings themselves, whereas in countries with weak institutions and lack of domestic savings, where aid is most needed, it is often squandered. In countries that grow fast aid works, in countries that do not grow, aid doesn't help much, except in emergency.

On top of that, the magnitude of foreign assistance seems to depend mostly not on the needs of the South, but on the attitude of the West towards developing countries and the balance of forces between the West and the South. Plotting the relative size of ODA over recent 5 decades reveals at least two important trends (fig. 11). First, despite rhetoric and intuition that more aid should be given to poorer countries in difficult times, it appears that aid increased when resource (oil) prices were high, and decreased, when they were low. Arguably, the bargaining positions of the South improved in times of more favorable terms of trade, so the West was trying to ensure that the greater financial independence of developing countries is not translated into more leftist political orientation. Second, the clear leveling off between 1991 and 2001, after the collapse of the Soviet Union and before the 9/11 terrorist attack, was probably caused by the perception of reduced security threats to the West in the period "after communism - before terrorism".

Arguably, aid is an over-researched issue and is less important than possible gains from any of the following reforms: elimination of Western protectionism and especially agricultural subsidies; more benevolent attitude of the 
West towards trade and exchange rate protectionism of the South; loosening of the intellectual property rights (IPR) regime for the South; allowing freer international migration of low skilled labor and efforts to stop brain drain from the South; control over the capital account and over FDI; recognition that the reduction of pollution should be done primarily by the West and that per capita emissions in the South can be as high as in the North; understanding that labor, environmental and human right standards in the South could differ from that in the North.

Figure 11. ODA and official aid to developing countries in current dollars (left scale) and oil prices per barrel in 2007 dollars (right scale)

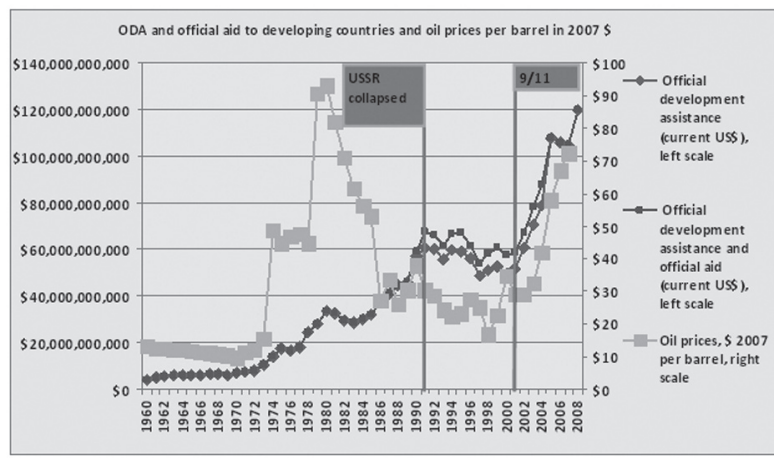

Source: WDI database.

To conclude, not all the countries that pursued the strategy of the mobilization of domestic savings achieved a breakthrough, some failed, but without such a mobilization there were no breakthroughs either. The same seems to be true about protectionism and industrial policy: not all the governments that tried to interfere into the allocation of resources by the market managed to succeed, but without such interference there were no economic miracles. To put it differently, mobilization of domestic savings and government policy of allocating these savings across industries appear to be a necessary, although not a sufficient conditions of the development success.

Why the Big Push does not work with mostly external savings? One reason may be that domestic savings follow investment opportunities - countries with strong institutions that create good investment climate raise the national savings rate nearly automatically. The other reason may be the proliferation in the global South of the special type of industrial policy that promotes growth of tradable goods and export sectors - undervaluation of domestic currency via accumulation of foreign exchange reserves. This nonselective industrial policy became very common in Asian countries in the second half of the XX century - first in Japan and South Korea in the 1950s-70s (before 1985 Plaza Accord), then in China since the 1980s - and later, since the 1997 Asian financial crisis - virtually in all major developing countries. This policy allowed keeping in check wages and prices for non-tradables, while giving a huge boost to tradables, exports, profits, savings and investment (POLTEROVICH; POPOV, 2004; GOSH, 2007; SPIEGEL, 2007; RODRIK, 2008).

This way or the other, economic miracles happened only in countries that relied on mobilization of domestic savings, not in countries that were seeking to bridge the financing gap through borrowing abroad, as development economists suggested. The crucial question then is how the national governments can mobilize domestic savings and to alter the allocation of resources in such a way as to achieve rapid, balanced sustainable and equitable growth. This is not only a matter of getting policies right, but also of having the appropriate institutional capacity that allows to design, adopt and enforce these right policies.

Development thinking is at the cross- 
roads. Development theories in postwar period went through a full circle - from Big Push and ISI to neo-liberal Washington consensus to the understanding that neither the former, nor the later really works in engineering successful catchup development.

The Big Push theorists were right in arguing for the mobilization of savings, but their theories had a couple of weaknesses. First, it turned out that foreign savings alone, without mobilization of domestic savings, cannot produce rapid growth. There were no cases of economic miracles based solely on foreign, not domestic, savings. Second, quite a number of national experiments involving mobilization of domestic savings on a massive scale failed. Domestic saving is a necessary, but not a sufficient condition of fast growth. Mobilization of domestic savings and even successful transformation of these savings into investment, does not guarantee fast growth. Investment should be channeled to projects with highest externalities and these projects have to finally pass the test of world market competition. Import substitution strategy could be good at the initial stages of the Big Push, but if it is not later supplemented by export orientation, it leads to the dead end: creation of non-viable industrial complexes not able to compete in the world market. Protection is a necessary condition of take-off growth, but should be supplemented with export promotion, if growth is to continue.

Washington consensus was an overreaction to the failure of ISI and the debt crisis of the 1980s - it threw the baby out of the bath together with the bathwater. It denounced not only import substitution, but also all types of industrial policies. And it denounced the need for special efforts to mobilize domestic savings. Meanwhile, the examples of fast growers - Asian tigers, South East Asia, China and India - all pointed out to the need for such mobilization and for the industrial strategy.

\section{New Paradigm}

The confusion in development thinking of the past decade may be a starting point for the formation of new paradigm. There is an emerging understanding that without mobilization of domestic savings and industrial policies there may be no successful catch up development. National development strategies for countries at a lower level of development should not copy economic policies used by developed countries; in fact, it was shown more than once that Western countries themselves did not use liberal policies that they are advocating today for less developed countries when they were at similar stages of development (CHANG, 2002; REINERT, 2007; FINDLAY, O’ROURKE, 2007).

This general principle - that good policies are context dependent and there is no universal set of policy prescriptions for all countries at all stages of development - is definitely shared by most development economists. But when it comes to particular policies, there is no consensus. The future of development economics may be the theory, explaining why at particular stages of development (depending on per capita GDP, institutional capacity, human capital, resource abundance, etc.) one set of policies (tariff protectionism, accumulation of reserves, control over capita; flows, nationalization of resource enterprises - to name a few areas) is superior to another . The art of the policymakers then is to switch the gears at the appropriate time not to get into the development trap. The art of the development theoretician is to fill the cells of the periodic table of economic policies at different stages of development.

The secret of "good" industrial policy in East Asia, as opposed to "bad" industrial policy in the former Soviet Union, Latin America and 
Africa may be associated with the ability to reap the benefits of export externality (KHAN, 2007; GIBBS, 2007). Exporting to the world markets, especially to developed countries, allows upgrading quality and technology standards and yields social returns that are greater than returns to particular exporters. It was shown that the gap between the actual level of development and the hypothetical level that corresponds to the degree of sophistication of a country's export is strongly correlated with productivity growth rates (HAUSMANN; HWANG; RODRIK, 2006). To put it differently, it pays off to promote exports of sophisticated and high tech goods. Not all the countries that try to promote such export succeed, but those that do not try do not ever engineer growth miracles.

Manufacturing growth is like cooking a good dish—all the necessary ingredients should be in the right proportion; if only one is underor overrepresented, the "chemistry of growth" does not happen. Fast economic growth can materialize in practice only if several necessary conditions are met simultaneously. In particular, rapid growth requires a number of crucial inputs — infrastructure, human capital, even land distribution in agrarian countries, strong state institutions, and economic stimuli among other things. Once one of the essential ingredients is missing, growth just does not take off. Rodrik, Hausmann, and Velasco (2005) talk about "binding constraints" that hold back economic growth; finding these constraints is a task in "growth diagnostics." In some cases, these constraints are associated with a lack of market liberalization, in others, with a lack of state capacity or human capital or infrastructure.

Why did economic liberalization work in Central Europe but not in SSA and LA? The answer, according to the outlined approach, would be that in Central Europe, the missing in- gredient was economic liberalization, whereas in SSA and LA, there was a lack of state capacity, not a lack of market liberalization. Why did liberalization work in China and Central Europe but not in CIS? Because in CIS, it was carried out in such a way as to undermine state capacity-the precious heritage of the socialist past, whereas in Central Europe and even more so in China, state capacity did not decline substantially during transition.

Take a closer look at the Chinese case. It is important to realize that the rapid catch-up development of the post-reform period is due not only to and even not so much to economic liberalization and market-oriented reforms. The pre-conditions for the Chinese success of the last thirty years were created mostly in the preceding period of 1949-76. In fact, it would be no exaggeration at all to claim that without the achievements of Mao's regime, the market-type reforms of 1979 and beyond would have never produced the impressive results that they actually produced. In this sense, economic liberalization in 1979 and beyond was only the last straw that broke the camel's back. The other ingredients, most importantly strong institutions and human capital, had already been provided by the previous (Mao's) regime. Without these other ingredients, liberalization alone in different periods and different countries was never successful and sometimes counterproductive, to put it mildly, like in Sub-Saharan Africa in the 1980s.

Market-type reforms in China in 1979 and beyond brought about the acceleration of economic growth because China already had an efficient government that was created by CCP after the Liberation and that the country did not have in centuries ${ }^{4}$ (LU, 1999). Through the par-

4 To a lesser extent, this is true for India: market-type reforms in the 1990 s produced good results because they were based on previous achievements of the import substitution period (NAYYAR, 2006). 
ty cells in every village, the communist government in Beijing was able to enforce its rules and regulations all over the country more efficiently than Qing Shi Huang Di or any emperor since then, not to mention the Kuomintang regime (1912-49). While in the late nineteenth century, the central government had revenues equivalent to only 3 percent of GDP (against 12 percent in Japan right after the Meiji Restoration) and under the Kuomintang government, they increased to only 5 percent of GDP, Mao's government left the state coffers to Deng's reform team with revenues equivalent to 20 percent of GDP. The Chinese crime rate in the 1970s was among the lowest in the world (SHANDONG, 2009), a Chinese shadow economy was virtually non-existent, and corruption, as estimated by Transparency International even in 1985, was the lowest in the developing world. In the same period, during "clearly the greatest experiment in the mass education in the history of the world" (UNESCO-sponsored 1984 report), literacy rates in China increased from 28 percent in 1949 to 65 percent by the end of the 1970s (41 percent in India).

The Great Leap Forward (1958-62) and the Cultural Revolution (1966-76) are said to be the major failures of Chinese development. True, output in China declined three times in the whole post-Liberation period: in 1960-62, by over 30 percent, in 1967-68, by 10 percent, and in 1976, by 2 percent (WDI database). The Great Leap Forward produced a famine, a rise in mortality and a reduction in the population. But if these major setbacks could have been avoided, Chinese development in 1949-79 would look even more impressive. Most researchers would probably agree that the Great Leap Forward that inflicted the most significant damage could have been avoided in the sense that it did not follow logically from the intrinsic features of the Chine- se socialist model. There is less certainty about whether the Cultural Revolution can be excluded from the "package" of subsequent policies this mass movement was very much in line with socialist developmental goals and most probably prevented the inevitable bureaucratization of the government apparatus that occurred in other communist countries. ${ }^{5}$ But the point to make here is that even without excluding these periods, Chinese development in 1949-79 was much better than that of most countries in the world and that this development laid the foundations of the truly exceptional success of the post-reform period.

To put it differently, by the end of the 1970s, China had virtually everything that was needed for growth except some liberalization of markets - a much easier ingredient to introduce than human capital or institutional capacity. But even this seemingly simple task of economic liberalization required careful management. The USSR was in a similar position in the late 1980s. True, the Soviet system lost its economic and social dynamism, growth rates in the 1960s-80s were falling, life expectancy was not rising, and crime rates were slowly growing, but institutions were generally strong and human capital was large, which provided good starting conditions for reform. Nevertheless, economic liberalization in China (since 1979) and in the USSR (since 1989) and later, Russia produced markedly different outcomes (POPOV, 2000, 2007a).

5 On June 15, 1976, when Mao's illness became more severe, he called Hua Guofeng and some others in and said to them: "I am over eighty now, and when people get old, they like to think about post-mortal things ... In my whole life, I have accomplished two things. One is the fight against Jiang Jieshi [Chiang Kai-shek] for several decades and kicking him out onto a few islands and fighting an eight-year resistance war against the Japanese invasion that forced the Japanese to return to their home. There has been less disagreement on this matter... The other thing is what you all know, that is, launching the "Cultural Revolution." Not very many people support it, and quite a number of people are against it. These two things are not finished, and the legacy will be passed onto the next generation. How to pass it on? If not peacefully, then in turbulence, and, if not managed well, there will be foul wind and rain of blood. What are you going to do? Only heaven knows" (People's Web, 2003).

6 Unlike Russia after 1991, it so far seems as if China in 1979-2010 managed to better preserve its strong state institutions - the murder rate 
The emerging theory of stages of development would hopefully put the pieces of our knowledge together and will reveal the interaction and subordination of growth ingredients. Successful export oriented growth model a la East Asian tigers seems to include, but is not limited to:

Building strong state institutions capable of delivering public goods (law and order, education, infrastructure, health care) needed for development

Mobilization of domestic savings for increased investment

\section{Gradual market type reforms}

Export-oriented industrial policy, including such tools as tariff protectionism and subsidies

Appropriate macroeconomic policy not only in traditional sense (prudent, but not excessively restrictive fiscal and monetary policy), but also exchange rate policy: undervaluation of the exchange rate via rapid accumulation of foreign exchange reserves.

in China is still below 3 per 100,000 inhabitants compared to about 30 in Russia in 2002 and about 20 in 2008 (Popov, 2007c). True, in the 1970 s, under the Maoist regime, the murder rate in Shandong Province (the national statistics is absent) was less than 1 (Shandong, 2009), and in 1987, it was estimated to be 1.5 for the whole of China (WHO, 1994). The threefold increase in the murder rate during the market reforms is comparable with the Russian increase, although Chinese levels are nowhere near the Russian levels. 


\section{References}

Acemoglu, Daron, Philippe Aghion, and Fabrizio Zilibotti. Distance to Frontier, Selection, and Economic Growth. June 25, 2002a. (http://post.economics.harvard.edu/faculty/aghion/papers/Distance to Frontier.pdf)

Acemoglu, Daron, Philippe Aghion and Fabrizio Zilibotti. Vertical Integration and Distance to Frontier. August 2002b. (http://post.economics.harvard.edu/faculty/aghion/papers/vertical_integration. pdf)

Acemoglu, Daron and James A. Robinson. "Why Did the West Extend the Franchise? Growth, Inequality and Democracy in Historical Perspective”, Quarterly Journal of Economics, CXV, 11671199, 2000.

Acemoglu, Daron and James A. Robinson. Economic Backwardness in Political Perspective. Unpublished paper. July 2005.

Acemoglu, Daron and James Robinson. Economic Origins of Dictatorship and Democracy, Cambridge University Press, 2006.

Bardhan, Pranab. Economics of Development and the Development of Economics. - Journal of Economic Perspectives, Vol. 7, No. 2, 1993 (Spring, 1993), pp. 129-142.

Bourguignon, François and Christian Morrisson, 'Inequality among world citizens: 1820-1992', American Economic Review 92(4), 2002, 727-744.

Chandrasekhar, C.P. Financial Policies. UN DESA, 2007;

Chang, H.-J. Kicking Away the Ladder. Cambridge University Press, 2002.

Chang, Ha-Joon. State Owned Enterprise Reform. UN DESA Policy Note, 2007 (http://esa. un.org/techcoop/documents/PN_SOEReformNote.pdf).

Easterly, W. The Lamentable Return of the Big Push. Proceedings of the German Development Economics Conference, Kiel 2005 / Verein für Socialpolitik, Research Committee Development Economics, at http://opus.zbw-kiel.de/volltexte/2005/3485/.

Easterly, W., Fisher, S. 1995. The Soviet Economic Decline. - The World Bank Economic Review, Vol. 9, No.3, pp. 341-71.

Feldman, G.A. 'On the theory of growth rates of national income', 1928, translated in: N. Spulber, ed., Foundations of Soviet strategy for economic growth. Bloomington, IN: Indiana University Press, 1964

Feldstein, Martin; Horioka, Charles. "Domestic Saving and International Capital Flows”, Economic Journal 90, 1980 314-329, http://www.jstor.org/stable/2231790?origin=crossref

Findlay, Ronald. 'The Trade-Development Nexus in Theory and History. UNU-WIDER Annual Lecture, October, 2009.

Findlay, Ronald, Kevin H. O’Rourke. Power and Plenty: Trade, War and the World Economy in the Second Millennium. Princeton University Press, 2009.

Galor, Oded . Economic Growth in the Very Long-Run. - Prepared for the New Palgrave Dictionary of Economics - 2nd edition (S. Duraluf and L. Blume, eds.), 1998.

Galor, Oded, D. Weil Population, Technology, and Growth: From Malthusian Stagnation to the Demographic Transition and Beyond. - American Economic Review, 90(4):806-828, September, 2000.

Galor, Oded and Omer Moav. Natural Selection and the Evolution of Life Expectancy. August 24, 2004 (http://129.3.20.41/eps/ge/papers/0409/0409004.pdf). 
Ghosh, Jayati. Macroeconomic and Growth Policies. Background Note. UN DESA, 2007.

Gibbs, Murray Trade Policy. UN DESA, 2007.

Goldstone Jack A. Unraveling the Mystery of Economic Growth. A review of Gregory Clark's "A Farewell to Alms: A Brief Economic History of the World". Princeton and Oxford: Princeton University Press. September, 2007. - World Economics, Vol. 8, No. 3, July-September 2007.

Goldstone, J. Comments on Popov, 2009. Unpublished.Hausmann, Ricardo, Jason Hwang, and Dani Rodrik (2006). “What You Export Matters,” NBER Working Paper, January 2006.

Khan, Mushtaq H. Investment and Technology Policies. UN DESA, 2007;

Kim, Dong Hyeon and Shu-Chin Lin (2009). "Trade and Growth at Different Stages of Economic Development”, Journal of Development Studies, 45.8, 2007, pp.1211-24.

Krugman, Paul. Finance mythbusting, third world edition. Nov 10, 2009. - Paul Krugman's blog: http://krugman.blogs.nytimes.com/2009/11/09/finance-mythbusting-third-world-edition/

Lu, Aiguo. China and the Global Economy Since 1840. New York, St. Martins Press, 1999.

Maddison, A. Statistics on World Population, GDP and Per Capita GDP, 1-2006 AD

(http://www.ggdc.net/maddison/Historical_Statistics/horizontal-file_09-2008.xls)

Malafeev, A.N. Istoriya Tsenoobrazovaniya v SSSR.1917-1963(The History of Price Formation in the USSR.1917-63). M., 1964, pp. 126-127, 136-137, 173.

Marx, Karl. Contribution to the Critique of Hegel's Philosophy of Right (1843). Marx-Engels Reader. Ed. By Robert Tucker. Oxford University Press, 1972.

Milanovic, Branko, 2009. "Global inequality recalculated: The effect of new 2005 PPP estimates on global inequality,” MPRA Paper 16538, University Library of Munich, Germany.

Milanovic, Branko, Peter H. Lindert, Jeffrey G. Williamson (2008). Pre-Industrial Inequality: An Early Conjectural Map. Mimeo, August 23, 2007 (http://www.economics.harvard.edu/faculty/williamson/files/Preindustrial_inequality.pdf)

Murphy, KM, A Shleifer, RW Vishny: Industrialization and the Big Push. The Journal of Political Economy Vol. 97, 1989, pp. 1003-1026

Naughton, Barry, Economic Reform in China. Macroeconomic and Overall Performance. - In: The System Transformation of the Transition Economies: Europe, Asia and North Korea. Ed. by D. Lee. Yonsei University Press, Seoul, 1997.

Nayyar, Deepak. INDIA'S UNFINISHED JOURNEY. Transforming Growth into Development. - Modern Asian Studies, Volume 40, Number 3, July 2006

O’Campo, Jose Antonio, Jomo K.S. and Rob Vos. Explaining Growth Divergences. In: Growth Divergences. Explaining Differences in economic Performance. Ed. by Jose Antonio O’Campo,. Orient Longman, Hyderabad, 2007.

Ortiz, Isabel . Social Policy UN DESA, 2007.

People’s Web. “Today in History: Mao Zedong Said: I Did 2 Things in My Life”. June 15, 2003 (http://www.people.com.cn/GB/tupian/1097/1914967.html). In Chinese.

Polterovich, V., V. Popov Accumulation of Foreign Exchange Reserves and Long Term Economic Growth. - In: Slavic Eurasia’s Integration into the World Economy. Ed. By S. Tabata and A. Iwashita. Slavic Research Center, Hokkaido University, Sapporo, 2004.(http://www.nes.ru/\%7Evpopov/ documents/EXCHANGE\%20RATEGrowthDEC2002withcharts.pdf).

Polterovich, V., Popov, V. Appropriate Economic Policies at Different Stages of Development. 
NES, 2005 - http://www.nes.ru/english/research/pdf/2005/PopovPolterovich.pdf.

Polterovich, V., Popov, V. Stages of Development, Economic Policies and New World Economic Order. Paper presented at the Seventh Annual Global Development Conference in St. Petersburg, Russia. January 2006.(http://http-server.carleton.ca/ vpopov/documents/NewWorldEconomicOrder.pdf).

Polterovich, V., Popov, V. Democratization, Quality of Institutions and Economic Growth. In: Political Institutions And Development. Failed Expectations and Renewed Hopes. Edited by Natalia Dinello and Vladimir Popov, Edward Elgar Publishing, 2007.

Polterovich, V., Popov, V. and Tonis, A. Resource abundance, political corruption, and instability of democracy. - NES Working Paper \# WP2007/73 (http://www.nes.ru/russian/research/pdf/2007/ PolterPopovTonisIns.pdf).

Polterovich, V., Popov, V. and Tonis, A. Mechanisms of resource curse, economic policy and growth. NES Working Paper, 2008. \# WP/2008/082 (http://www.nes.ru/english/research/pdf/2008/Polterivich Popov.pdf).

Popov, V. Shock Therapy versus Gradualism: The End of the Debate (Explaining the Magnitude of the Transformational Recession) - Comparative Economic Studies, Vol. 42, No. 1, Spring 2000, pp. 1-57 (http://www.nes.ru/\%7Evpopov/documents/TR-REC-full.pdf);

Popov, V. Shock Therapy versus Gradualism Reconsidered: Lessons from Transition Economies after 15 Years of Reforms. - Comparative Economic Studies, Vol. 49, Issue 1, March 2007a, pp. 1-31(http://www.nes.ru/\%7Evpopov/documents/Shock\%20vs\%20grad\%20reconsidered\%20-15\%20 years\%20after\%20-article.pdf).

Popov, V. Life Cycle of the Centrally Planned Economy: Why Soviet Growth Rates Peaked in the 1950s. In: Transition and Beyond. Edited by: Saul Estrin, Grzegorz W. Kolodko and Milica Uvalic. Palgrave Macmillan, 2007b.

Popov, V. Russia Redux. - New Left Review, No. 44, march-April,2007c.

Popov, V. Lessons from the Transition Economies. Putting the Success Stories of the Postcommunist World into a Broader Perspective. - UNU/WIDER Research Paper No. 2009/15.

Popov, V. Why the West Became Rich before China and Why China Has Been Catching Up with the West since 1949: Another Explanation of the "Great Divergence" and "Great Convergence" Stories. -NES/CEFIR Working paper \# 132, October 2009.

Preobrazhenski, E., The New Economics. (1926), Oxford: Clarendon Press, [1965].

Reinsert, Erik S. How Rich Countries Got Rich... And Why Poor Countries Stay Poor. Constable, London, 2007.

Rodriguez, Francisco. Openness and Growth: What have We Learned? - In: Growth Divergences. Explaining Differences in economic Performance. Ed. by Jose Antonio O’Campo, Jomo K.S. and Rob Vos. Orient Longman, Hyderabad, 2007.

Rodriguez, Francisco and Dani Rodrik. TRADE POLICY AND ECONOMIC GROWTH: A Skeptic's Guide to the Cross-National Evidence. CEPR Discussion Paper No. 2143, 1999.

Rodrik, Dani . Getting Institutions Right. CESifo. Journal for Institutional Comparisons. Vol. 2, No. 4, Summer 2004.

Rodrik, Dani, R. Hausmann, A. Velasco (2005). Growth Diagnostics. 2005. http://ksghome. harvard.edu/ drodrik/barcelonafinalmarch2005.pdf 
Rodrik, Dani WHAT'S SO SPECIAL ABOUT CHINA'S EXPORTS? Harvard University, January 2006. Http://www.hks.harvard.edu/fs/drodrik/Chinaexports.pdf

Rodrik, Dani The Real Exchange Rate and Economic Growth revised, October 2008. Undervaluation is good for growth, but why? Http://www.hks.harvard.edu/fs/drodrik/RER\%20and\%20 growth.pdf

Rodrik, Dani, Arvind Subramanian and Francesco Trebbi. Institutions Rule: The Primacy of Institutions over Geography and Integration in Economic evelopment. October, 20022002 (http://ksghome.harvard.edu/ .drodrik.academic.ksg/institutionsrule,\%205.0.pdf).

Rosenstein-Rodan, P.N. The Problems of Industrialisation of Eastern and South-Eastern Europe. The Economic Journal, Vol. 53, No. 210/211. Jun. - Sep., 1943, pp. 202-211.

O’Rourke, K. H. and R. Sinnott, 2001. “The Determinants of Individual Trade Policy Preferences: International Survey Evidence,” Trinity College Dublin Economic Papers 200110, Trinity College Dublin Economics Department.

O’Rourke, Kevin H. \& Jeffrey G. Williamson, 2002. "From Malthus to Ohlin: Trade, Growth and Distribution Since 1500,” NBER Working Papers 8955.

Sachs, J.D. and A.M. Warner . The big push, natural resource booms and growth. - Journal of Development Economics, vol.59, 1999, 43-76.

Shandong. Shandong Province data base [Shandong sheng shengqing ziliaoku], 2009. Http://www.infobase.gov.cn/bin/mse.exe?seachword=\&K=a\&A=16\&rec=42\&run=13 http://bbs.tiexue.net/post_1207004_1.html .

Shmelev, N. Popov, V. The Turning Point: Revitalizing the Soviet Economy. Doubleday, 1989.

Spiegel, Shari. Macroeconomic and Growth Policy. Policy Note. UN DESA, 2007.

Stalin, J. Interview with Foreign Workers' Delegations. November 5, 1927. Works, Vol. 10, August - December, 1927. Foreign Languages Publishing House, Moscow, 1954.

Stalin, J. V. THE TASKS OF ECONOMIC EXECUTIVES.From J. V. Stalin, Problems of Leninism, Foreign Languages Press, Peking, 1976, pp. 519-31. http://marx2mao.com/Stalin/TEE31.html

Toye, John. Development Theory and Experiences of Development. Issues for the Future, 1989

Toye, John. Development in an interdependent world: old issues, new directions? Background paper for WESS 2010.

WDI database. World Bank, 2010.

Williamson, Jeffrey G. Winners and Losers over Two Centuries of Globalization, 2002 WIDER Annual lecture 6. WIDER/UNU, November 2002.

WIPO. World Intellectual Property Indicators. WIPO, Geneva, 2009. 
